\title{
Marketing channels in value creation and delivery of cheese in the Republic of Serbia
}

\section{Канали маркетинга у креирању вредности и испоруци сира у Републици Србији}

\section{Goran Petković}

University of Belgrade, Faculty of Economics, Belgrade, Republic of Serbia, goran.petkovic@ekof.bg.ac.rs

\section{Dubravka Užar}

University of Novi Sad, Faculty of Agriculture, Novi Sad, Republic of Serbia, dubravka.uzar@polj.uns.ac.rs

\begin{abstract}
Although the use of various forms of marketing channels is increasing within agricultural marketing, there have been only a limited number of research efforts exploring the influencing factors on the structure of agricultural marketing channels and the decisions to select individual intermediaries. Due to the specific nature of agricultural production and its products, complex transportation and storage problems require a greater number of intermediaries in their movement from producers to consumers. Management of sales channels is an important factor for the success of farmers, so it is necessary to evaluate the impact of changes in the environment on them. In order to adapt sales to the demands of the contemporary market, cheese producers are faced with the dilemma of expanding existing sales channels, adding modern channels to existing traditional channels, or making more radical changes to the market access. This paper defines the distribution methods and key players in cheese delivery that should point to strengthening the competitiveness of producers in the global market.
\end{abstract}

Key words: cheese, marketing channels, agriculture, marketing, commerce

JEL classification: Q13, M31

Сажетак: Иако се употреба различитих облика маркетиншких канала повећава у пољопривреди, постојао је само ограничен број истраживачких напора усмерених ка откривању фактора који утичу на структуру пољопривредних маркетиншких канала и на одлуке о одабиру појединачних посредника. Због специфичности пољопривредне производње и њених производа, комплексни проблеми транспорта и складиштења захтевају већи број посредника у њиховом кретању од произвођача до потрошача. Управљање каналима продаје битан је фрактор успешности пољопривредних произвођача, тако да је неопходно оценити утицај промена у окружењу на исте. Како би прилагодили продају захтевима савременог тржишта, произвођачи сира се налазе пред дилемом да ли само да прошире постојеће канале продаје додавањем савремених канала већ постојећим традиционалним каналима, или да размишљају о радикалнијим променама тржишног наступа. У овом раду дефиинишу се начини дистрибуције и кључни играчи у испоруци сира који би требали да укажу на јачање конкурентности произвођача на глобалном тржишту.

Corresponding author 
Кључне речи: сир, канали маркетинга, пољопривреда, маркетинг, трговина JEL класификација: Q13, M31

\section{Introduction}

Marketing channel management encompasses all the activities of the company involved in making the product available to targeted consumers. The most common marketing channels include wholesale, retail, various service providers and direct consumers. Many small manufacturers-entrepreneurs mistakenly believe that introducing a new product to the market involves only finding a retailer who will be selling it or a distributor that can handle market dissemination. Finding a market for a new product is not so easy. A marketing channel is a complex system based on selection of the number and types of markets, regulating the intensity of coverage of different market areas, managing product types and quantities for different markets, and managing inventory, transportation and logistics. Finally, point-of-sale management involves making the product suitable for targeted customers and their purchase (Center Food Processing, 2001; Đokić, 2018). The first step in learning about the marketing and distribution system is to learn about the process by which a product reaches consumers.

Food distribution is a specific system of shifting goods from producers to consumers (Lovreta et al., 2019). It contains unique elements such as different storage and transportation including numerous players, from manufacturers and processors to brokers, distributors and sales representatives to consumers. Marketing channels are also defined as sets of interdependent organizations involved in the process of making a product or service available for use or consumption. Channels represent a set of pathways by which a product or service moves after production, culminating in end-user purchase and use (Kotler \& Keller, 2006).

Manufacturers, trade companies and end users perform their function in the channels. Marketing channels include the total flows of goods, money, and information flowing among institutions. The functions of exchange, physical supply and service are inherent in the marketing and commerce system (Lovreta et al., 2019). Due to the globalization of trade, competition among businesses has intensified. Therefore, in addition to high quality products, effective promotion and competitive pricing, product distribution is also an important segment of differentiation. Thus, delivering products to the end consumer faster and more efficiently than competitors becomes a key success factor (Mehta et al., 2003). Successful global marketing channels require the alignment of product quality, the diligence of market researchers to determine the validity of product sales in a particular area, the selection and development of marketing channels and representatives, and the appropriate motivational and leadership skills necessary to succeed (Palombo, 2009). Marketing channels are becoming more important because, thanks to this element of the marketing mix, products become available in the form, place and time preferred by consumers (Szopa \& Pekala, 2012). Therefore, one of the key roles of marketing channels is to turn potential customers into profitable customers 
(Kotler \& Keller, 2016). Revzan (1961) was among the first to appreciate the specificities of agricultural products, identifying channels of distribution of agricultural products, either processed (industrial processing, final consumption) or unprocessed products, directly distributed to final consumers. Through market research, management of channels identifies not only the needs and desires of consumers, their motives and behaviors, but also the behavior of other key market players (Stanković, 2014). Therefore, in the further analysis we are focusing on the distribution channels of agricultural products, that is, even more focused, on the marketing of cheeses, which are significantly different from the sales channels of other products. The subject of this research is cheese production by small producers, oriented to production and marketing.

The aim of the research is to present the structure of distribution channels as well as their role in the value creation and delivery of cheese by small producers and to find out the answer to the key question: which distribution channel will be selected by the cheese manufacturer when entering the market.

\section{Research project and methodology}

During the period June- November 2017, the project "Contemporary Trends on the Wine Market" took place in Serbia. The focus was on analyzing consumer behavior related to wine consumption. Methods of data collection were desk research, in-depth interviews and interviewing of 200 respondents in Serbia. Based on this research, a new project entitled "Study of consumers' attitudes of cheese consumption" has been granted.

The research will cover a sample of 500 respondents in Vojvodina and Hungary. This research is directed to explain and predict the beliefs influencing consumer needs and the motivations behind their purchase decisions, when cheese is in question. The main aim of the research is to understand the consumer preferences regarding the purchase and consumption of cheese, as well as the main factors that largely determine the behavior of cheese consumers in Vojvodina and Hungary.

This paper is a desk-based research effort on a narrower segment of this project that addresses marketing channels. The consumption of each product, including cheese, depends significantly on how the product is made available to the market: where it is available, at what prices, in what packaging, etc. Consumer desires are often shaped by the work of participants in marketing channels. That is why, when it comes to selling more value-added products, the right choice of marketing channels significantly affects the prices achieved and the competitive advantage of the product in the market. Before examining the final consumers, through this research of adequate literature, a basis was prepared for forming a questionnaire and generating basic research questions. A key research question in this segment of cheese marketing is whether to sell through direct or indirect marketing channels. 


\section{Research results}

\subsection{Characteristics of agricultural distribution channels}

When it comes to marketing agricultural products, the most complex problem is a proper and adequate distribution system, and in particular a physical distribution system (Milisavljević, 2019).

Much specificity is present in the marketing of agricultural products. First of all, there is a time gap between production and consumption: production is seasonal and consumption has its continuity (Lovreta et al., 2019). Second, there is no possibility of changing the quantity of products during the production process, which is conditioned by variations in yields that generate the need to reduce the risk through different degrees of vertical cooperation and channel integration (Zwart \& McLeay, 1997). Although technical and technological progress allows for a certain shortening of the production process, it is not possible to adjust the volume and quality of supply of final products to changes in demand during the production cycle in agriculture. The third specificity is reflected in the fact that there is a geographical separation of producers and consumers, and that producers are most often located, i.e. concentrated in several locations, while consumers dispersed in a large number of locations (Nikolić \& Popović, 2016). Also, transportation and storage problems are very complex, requiring a large number of intermediaries in the movement of products from producer to consumer. Many agents and service providers result in high distribution costs for agricultural products, which are included in the price paid by consumers (Miljković \& Alčaković, 2015). Not all commodities can be produced on all agricultural land due to variations in agro-climatic conditions. Therefore, there is a need to transport some products from remote manufacturers to consumers. In addition, there are a large number of small producers in Serbia with low market share, which requires the presence of adequate marketing channels. In this sense, their task is to buy smaller quantities of products from small producers, concentrate stock and only then distribute goods in the quantities demanded to a larger number of consumer sites (Nikolić \& Popović, 2016).

Channels where the manufacturer is in direct contact with customers are called direct distribution channels (Fernie \& Sparks, 2009). The second direction that agricultural products reach consumers involves intermediaries, so that in the marketing of agricultural products we distinguish:

(i) Direct channel: In this case, intermediaries are completely absent. This type of sales has a very small market share. Examples of direct marketing when it comes to agricultural products are green markets, farm sales, roadside stands, etc. Advantages of direct marketing are reflected in: absence of special requirements for sales volume, flexibility in product packaging, product promotion in the form of demonstrations, billboards, etc., direct access to market information such as consumer preferences, 
willingness to pay, etc. (Coughlan et al., 2006). The advantage of selling on the farm is reflected in the absence of transportation costs and customer loyalty to the products. Also, the direct markets are suitable for the emergence of new, inexperienced manufacturers with smaller quantities offered.

(ii) Indirect channel: Agricultural goods generally move from producers to consumers through intermediaries. The number of intermediaries can vary from one to many. Indirect marketing channels through intermediaries allow manufacturers maximum specialization in performing their primary business, then producing larger quantities of products and realizing the effects of economies of scale (Nikolić \& Popović, 2016). The modern specialized economy implies increased horizontal and vertical distance between producers and consumers, which has resulted in a decrease in direct sales (Zakić et al., 2018). The role of market intermediaries has increased recently, as a significant proportion of products pass through them.

Most agricultural products move towards consumers through several intermediaries and channels whose role is essential as they carry out important marketing functions and help to expand the agricultural market. A very small share of agricultural products is directly moving from farmers to consumers (Miljković \& Alčaković, 2015). Nevertheless, direct marketing channels in agricultural product sales are, to some extent; constantly present (Nikolić \& Popović, 2016). Green markets are a big part of the turnover of some agricultural products, where the farmer produces, prepares and distributes the products physically (Stanković, 2018). The prices at which producers sell at the green market are far above the prices paid by dairies, and are slightly lower than the retail prices. According to the research by Miljković and Alčaković (2015), the green market is very important in vegetable trade (average for 2009-2013 - 76, 32\%), dairy products $(19,01 \%)$, and fruit and grapes $(39,01 \%)$ ) while negligible in other product groups. The much higher prices of products achieved by farmers at the green market compared to the purchase prices by retail stores are the reason why they turn to this channel. Farmers need to consider the implications of each channel or consider using multiple options and traditional and complex sales channels for their products (Radosavljević, 2017).

- Marketing channels reflect the goals of the businessmen and indicate the quality and desired way of positioning the product, which is why it is necessary to consider the following factors before choosing specific marketing channels (Marušić, 2006):

- The distribution channel should match the image of the product and the perception of the product features that customers have; 
- Signals from monitoring market changes and adjustment of the distribution to changes that have occurred;

- Control of product handling in the selected channel, relating to sales staff and their product knowledge, as well as shelf merchandising of the products;

- Number of competing products offered by a particular distributor, etc.

An important factor is also the analysis of consumer behavior that helps to understand what kind of channel structure is needed to meet the target market segments.

\subsection{Cheese distribution channels}

In the cheese making process, the exchange transaction, as a significant link in the chain and the delivery of value to customers and consumers, occurs repeatedly in the reproduction cycle: through the acquisition of production inputs for milk production, then in the process of physical transformation of the raw material, the emergence of the finished product, up to the point of sale cheese to final consumers (Figure 1).

Exchange is products values creation phase in which consumers evaluate a product and thus determine its position in the market. A market-oriented producer looks for a way to secure the market placement of manufactured goods and finally complete the reproduction cycle through the sale and collection of receivables for sold products, or through the market acceptance of finished products (Tihi et al., 2006). Market distribution is an important element in the value chain of cheese, especially due to the fact that it is a food item whose production requires milk of proven quality, under controlled conditions, should reach processors as soon as possible. It is also necessary to deliver the cheese as a finished product, at minimal cost, to consumers at the right place and time, in the right quantities and at the right price.

An effective marketing channel management strategy begins with consumer segmentation. In the first place, it is necessary to identify behavior, needs, lifestyle, loyalty level and the way end consumers use the product, as well as to specify belonging to a particular social class, to understand their opinions, activities and attitudes (Rolnicki, 1998). In making marketing channel decisions for the purposes of cheese marketing, it is necessary to distinguish marketing channel design activities from marketing channel participants' selection activities.

Channel design refers to decisions that involve developing new marketing channels or modifying existing ones (Rosenbloom, 2013). Selection decisions relate to new entrants, the numerical and weight distribution of the product (Berman, 1996) whereby the channel structure, depending on the length and type of entrant, may remain the same. What needs to be taken into account when deciding which marketing channel to choose is the goal of the business, the procedures used to achieve those goals, and how to meet customer needs (Pelton et al., 2016). 
When deciding on the choice of participants in the marketing channel we want to create, we need to consider (Vasiljev \& Sudarevic, 2014): the financial and creditworthiness of the potential distributor; bandwidth, i.e. the volume of sales that the distributor can generate; sales capacities, in terms of sales space, storage area, available transport equipment, etc.; the width of the range covered by the distributor; degree of "market coverage"; the human capacity of the distributor human factor; reputation enjoyed by the distributor among business people and the like.

Figure 1: Cheese marketing channels

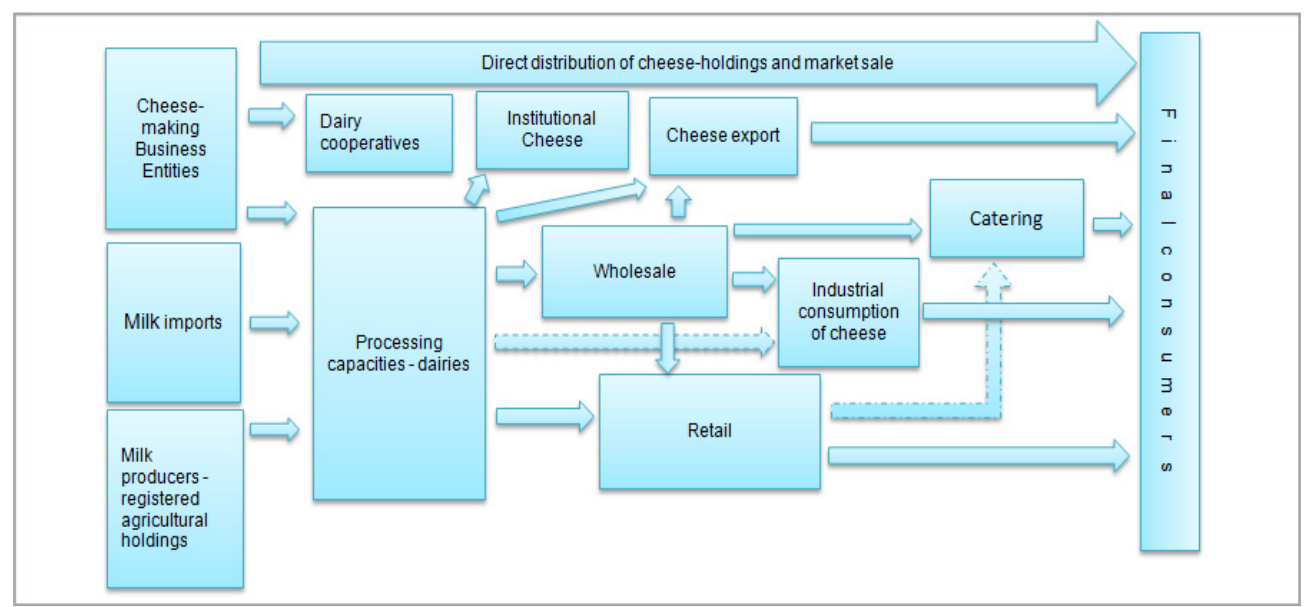

Source: the authors' research

In economically developed countries, dairy cooperatives have a strategic importance. In the Republic of Serbia, unlike in developed countries, there is no functional cooperative network (Chroneos-Krasavac \& Petković, 2015). This is why, among other things, producers of cheese and other dairy products are increasingly focusing on milk imports. In the final outcome, this leads to a decline in the milk cap stock, as well as a decline in the number of milk producers (Lončar \& Ristić, 2011). The absence of cooperatives, as significant business entities in cheese marketing channels and value chains, also leads to a decline in the quality of cheese offered by domestic producers and increasing import dependencies, to meet market demand for this final product.

One aspect of the modernization of food marketing channels is the growth in the market share of large retail chains selling through supermarkets and hypermarkets (Minot \& Roy, 2007). According to a survey conducted in 2011 by the research agencies Nielsen and GfK (www.progressivemagazin.rs), the most important cheese distribution channels in Serbia are hypermarkets and supermarkets, but the share of small shops in sales is very significant and shows growth tendency. So, while the share of supermarkets and hypermarkets is dominant, many consumers are loyal to smaller 
stores and even specialty dairy stores to sell cheese. One reason is the fact that, according to the experience of large domestic retailers, just over $50 \%$ of the turnover is generated by soft white cheese, unlike in Western countries where semi- durable, semi-hard and hard cheeses are extremely prevalent.

When it comes to marketing channels from a manufacturer's perspective, their transformation is still ongoing and raises concerns. According to a study by Mugoša (2018) in the selection of distribution channels, with the possibility of multiple choice of different channels, $78 \%$ of agricultural producers (farms with domestic milk processing facilities) opt for direct channel, i.e. green market sales, which indicates the predominant traditional distribution method. The share of catering establishments $(16 \%)$ and pastry workshops (6\%) that farms sell cheese to is significantly lower. The current legislation of the Republic of Serbia, except for the markets, does not clearly define whether and where the registered agricultural producers of primary products or products can sell (Kovács-Sárkány \& Kovács, 2015). The choice of marketing channels from the offer of individual agricultural households owning their own dairy processing facilities in the Republic of Serbia is subject to legal restrictions which prescribe only two ways of sale: from home and at the market (Veterinary Law, Official Gazette 93/2012). This fact is a limitation for cheese-makers, but also an argument in support of the statement of the need for their association.

Although in accordance with the Law on Trade (Official Gazette RS No. 52/2019, Art. 25), the agricultural producer has the status of trader, laws and by-laws regulating the field of trade in milk products from the production of registered agricultural households do not recognize this the way of sale or distribution. The legal framework governing the processing and marketing of milk and milk products offered by the registered agricultural households of the Republic of Hungary, as a member of the European Union, as well as its practice, may be the basis for the improvement of this area in the Republic of Serbia. Small producers sometimes open a retail outlet, which has an assortment of cheeses and other dairy products from its own production. In these retail stores, manufacturers have the ability, through a certain way of exposing cheese, sometimes with an insight into part of the final production operations, tasting opportunities, specific service, promotional and other marketing activities, to offer consumers a characteristic retail experience other than competition. In this way, the producer creates stronger ties with the consumer, adds value to the cheese and creates the ability to set the desired standard for the sale of cheese, both in his own and in the facilities of other retailers. The limiting factor for the placement of cheese through its own retail establishments is the insufficient breadth and depth of the assortment, that is, the narrowed choice in terms of variety, type and characteristics of cheese.

When it comes to indirect distribution channels, small and medium-sized cheese-making businesses mainly rely on channels that include wholesale, retail, catering and hotels. In addition to these indirect channels, informal flows are also taking place, within which the practice of direct delivery of cheese to schools, pastry makers, 
etc. by cheese producers on registered agricultural households is ongoing (Mugoša, 2018). Distribution channels are diversified, but they are mostly informal because the legal framework limits distribution to sales from home or green markets. In this respect, the presence of certain cheese in distribution channels depends largely on the economic power of producers and their ability to respond to the requirements for granting high rebates and paying other fees necessary to enter retail chains. In order to achieve cost-effectiveness and higher sales volumes, manufacturers are focusing on an undifferentiated supply of a modest range of cheese, which, although often of better quality than foreign competitors, comes to the market without focusing on any market segment and the value that cheese has for that segment. Other indirect distribution channels in most cases are dairy shops, home sales for well-known customers, small retail shops, etc. Bakery workshops buy low quality cheese and are not prepared to pay the price for the right quality cheese.

A significant player in marketing channels is wholesale, whose position as intermediaries is largely influenced by the growing power of retail chains. In fact, growing retailers are increasingly making direct business arrangements with manufacturers. The sale of farmers through wholesale brokers can be explained by the following factors: the need for specialized knowledge and contacts in specific markets, the exemption from stockpiling finished products, the ability to provide more information about products from different manufacturers, the possibility of faster delivery at a lower price, etc. What is in the common interest of cheese producers and wholesalers is their business cooperation, whereby wholesalers need to provide top quality services, continually adjusting to changes, and have timely information on demand and other market changes.

- The ability to enter the market through large retail chains is significantly determined primarily by the business goals of both parties, as well as contractual terms relating to quality, prices and various fees that smaller manufacturers often cannot meet. The prominent role of large retail chains in the growth and development of manufacturing businesses requires cheese producers to have a high level of information on trends within modern marketing channels. Also, it is necessary to consider sometimes blurred facts about structural and functional changes within the channels that are constantly occurring (Lovreta et al., 2019):

- declining producer and conversely growing retailer strength in marketing channels;

- development of an active role of retailers in collecting consumer data and in the overall implementation of marketing activities;

- speeding up the flow of all consumer - store - retail company - wholesaler manufacturer data and deriving from these data needed information to replace traditional stock holding with timely ordering; 
- integration of a total product supply chain that focuses on retailers capable of accurately assessing future sales funnels.

Domestic market saturation, the growth and development of large retail chains can also lead to their entry into foreign markets, which is one way to market more domestic producers to a foreign market. The presence of retailer brands, which often occupy the best positions on the shelves, is a danger and puts the cheese producers at a disadvantage. For some smaller manufacturers, on the other hand, it will be a chance to sell their products and, leaving retailers with marketing problems, focus their efforts on production and quality.

The existence and increase of competitiveness of cheese producers vis-à-vis large retail chains requires their integration and association, quality improvement and development of cheese brands alongside the formation of a joint offering. By acting together, it is possible to provide a more comprehensive range of offers tailored to consumer requirements, better market position and coverage, and even greater bargaining power.

The process of transforming production inputs into cheese as a final product, and delivering it to the final consumer, may involve different participants who add value and thus form marketing channels. The final, delivered value depends on the internal performance of each individual participant as well as the type and quality of their interconnections. The value chain represents the full range of activities needed to bring a product or service, from conception, through different stages of production (including different combinations of physical transformation as well as participation of different services) to the end consumer, with final disposal and removal after use (Kaplinsky et al., 2001). When it comes to cheeses, value-adding takes place in production (milk quality, recipes, maturing), during the logistics process (packaging, delivery accuracy), but also during the sale itself (offered store assortment, brand selection, display, optimal pricing, etc.).

Milk-producing households may choose to sell raw materials to local dairies or to produce cheese as value-added products. They may further, as individuals or associated in cooperatives or other type of associations, produce cheese whose production, in addition to specific knowledge, production technology, location, etc., requires special storage and ripening conditions, transport services, etc. This high value production further increases the value of cheese but also enhance the image of the region.

Cheese with protected geographical indications (GI), organic cheese, cheese ripening and specific cheeses, have added value. Their market valuation and placement are conditioned by the identification and selection of market segments. It is necessary to identify segments of consumers who want such value. Furthermore, market valorization is also conditioned by the choice of functional marketing channels, which will make these products available to consumers, at the required time and place, quantities required and preferred form. Due to their unique properties resulting from the condi- 
tions and technology of production, limited territories of origin, etc., these cheeses have a distinct image in relation to industrial cheeses. Differentiation contributes to a better competitive position of producers and stronger bargaining power in marketing channels.

\subsection{The geographical indication of origin and tourism as a new channel for selling cheese}

The association of the geographical origin (GI) of a particular product with specific quality characteristics has been known throughout history. The protection of the geographical origin of agricultural products is now legally regulated, but there is extensive literature discussing the economic effects of this activity. The 2018 FAO report discusses several key impacts (Vandecandelaere et al., 2018).

Selling at higher prices is the most commonly discussed effect of geographical identification (GI) of a product. Through case studies of numerous agricultural products, prices of geographically specified products, which are more than average in the range of $10-50 \%$, are stated. Achieving additional external effects through the protection of the natural environment, the protection of certain plant and animal varieties, traditional practices and intangible cultural heritage is also a frequently discussed positive effect of these legal activities.

Finally, a significant part of the professional literature deals with the positive effects of protecting the geographical origin of agricultural products on tourism. Particularly cited are examples of famous cheeses, including buffalo mozzarella from Campania, camembert from Normandy, Brie de Melun, the first of many Brie cheeses originating in the Seine and Marne valleys, etc. Those who have traveled through southern Italy, especially the province of Salento, could spot numerous examples of agrotourism with small mozzarella workshops where you can learn something about production, taste cheese and buy freshly made produce. There are almost no tourists in Sardinia who have not tried the famous Sardi Pecorino. Likewise, most visitors to France go home with a small collection of high-flavored vacuum-packed cheeses. Similar is the case with visitors to the Netherlands, who have prepared many packages of standard and aged ripe hard cheeses in tourist shops, along with collections of bulb tulips.

The preceding examples show the parallel existence of direct and indirect channels of placement of these products in tourist destinations. If cheese producers apply direct marketing, they sell the cheese directly to the end consumer on the farm, in a permanent or mobile green market, within the package of rural and wine tourism, through retail establishments of associated producers. The strong reputation of these products indicates a relationship of trust and a built image of the local product. The 
ability to taste and evaluate the taste and quality at the point of sale ensures that feedback is received, which improves experience and visitor satisfaction.

Producer association provides the opportunity to use indirect marketing channels, i.e. to involve intermediaries between producers and end consumers and to enter into a more complex channel system in the domestic and international markets. These intermediaries may be distributors, entities that deal with the ripening and distribution of cheese, specialized stores for the sale of cheese, organic food stores, etc. However, the most important indirect channel in tourist destinations is HoReCa sector. Decisions about marketing channels are of strategic importance for businesses, which is why the choice of participants and their structure should be in line with other marketing mix instruments, in a way that allows the market value of the cheese to be marketed.

\section{Conclusion}

Delivering a product to a place and time when there is a solvency demand for it is one of the essential functions of a marketing channel. Which marketing channel a small producer will opt for in the first place depends on the target consumer segment, but also on the set goals of the farm, then on the size of production capacities, the type and characteristics of the cheeses themselves and other conditions.

Direct marketing channels provide a more direct link between the farm household and consumers and create long-term relationships based on trust, which enables a better understanding of consumer needs, wants, requirements and preferences. When it comes to indirect channels with many intermediaries involved, this link is much looser. On the other hand, the specialization of participants in the marketing channel allows reducing costs but only in conditions of large production. Indirect sales in the context of small quantities of artisanal products result in high costs for the sale of agricultural products, which are included in the price and are paid by consumers. Within the basic division of consumer distribution channels into direct and indirect, cheese producers generally rely on indirect channels, which include wholesale, retail, restaurants and hotels. However, a large number of small producers are committed to direct sales through the green market, which indicates the predominant traditional way of distribution.

Which distribution channel the cheese maker will choose depends primarily on the economic power of the producer and their ability to respond to the payment requirements required before entering retail chains, as well as their ability to meet the needs of the target market segment. 


\section{References}

Berman B. (1996). Marketing Channels. New York: John Wiley \& Sons Inc.

Center, Food Processing, "The Specialty Cheese Market" (2001). Reports from the Food Processing Center, University of Nebraska-Lincoln. 9. Available at: https://digitalcommons.unl.edu/fpcreports/9/

Coughlan, A. T., Anderson, E., Stern, L. W., \& El-Ansary, A. (2006). Marketing Channels. (7th ed.). Prentice Hall.

Chroneos-Krasavac, B., \& Petković G. (2015). Zadruge u Srbiji - razvoj i aktuelna pitanja. Ekonomika poljoprivrede, 62(3), 723-735.

Doi: https://doi.org/10.5937/ekoPolj1503723C

Đokić, I. (2018). Economic effects of integrated marketing communications: The case of food products. Ekonomika poljoprivrede, 65(3), 985-994. Doi:

https://doi.org/10.5937/ekoPolj1803985D

Fernie, J., \& Sparks, L. (2009). Logistics \& Retail Management: Emerging issues and challenges in the retail supply chain, 3rd Edition. London: Kogan Page.

Kaplinsky, R., \& Morris, M. (2001). A Handbook For Value Chain Research International Development Research Centre (IDRC). Brighthton: Ins Development Studies (IDS)

Kotler, P., \& Keller, K. (2006). Marketing menadžment. Beograd: Data Status.

Kotler, P. and Keller, K. (2016). Marketing Management. 15th Global Ed. Pearson Prentice Hall.

Kovács-Sárkány. H., \& Kovács, V. (2015). Prerada prehrambenih proizvoda u okviru gazdinstva - praksa u Mađarskoj, mogućnost u Srbiji. The Central European Journal of Regional Development and Tourism, 7(1), 110-119.

Lončar, D., \& Ristić, B. (2011). Analiza konkurencije i tržišne koncentracije u sektoru mlekarstva u Srbiji. Ekonomika preduzeća, 59(1-2), 125-142. Doi: https://doi.org/10.5937/ekopre1102125L

Lovreta, S., Končar, J., Petković, G. Bogetić Z., \& Stojković D., (2019). Kanali marketinga. Beograd, Srbija: CID-Ekonomski fakultet Beograd i Ekonomski fakultet Subotica.

Marušić, M. (2006). Plan marketinga. Zagreb: ADECO.

Mehta, R., Dubinsky, A. J., \& Anderson, R. E. (2003). Leadership style, motivation and performance in international marketing channels. European journal of marketing, 37(1/2), 50-85. Doi: https://doi.org/10.1108/03090560310453939 
Milisavljević, M. (2019). Marketing. Beograd: Savremena administracija.

Miljković, M., \& Alčaković, S. (2015). Kanali distribucije poljoprivrednih proizvoda sa posebnim osvrtom na pijace u Srbiji. In Synthesis 2015-International Scientific Conference of IT and Business- Related Research, Singidunum University, 599-602. Doi: https://doi.org/10.15308/Synthesis-2015-599-602

Minot, N., \& Roy, D. (2007). Impact of high-value agriculture and modern marketing channels on poverty: An analytical framework. International food policy research institute, Washington, DC: Markets, Trade, and Institutions Division, International Food Policy Research Institute.

Mugoša, I. (2018). Primena marketing koncepta u funkciji unapređenja proizvodnje i plasmana sira u Republici Srbiji, doctoral dissertation, University of Novi Sad, Faculty of Agriculture.

Nikolić, M. M., \& Popović, A. (2016). Specifics of marketing in overcoming discrepancies on the market of agricultural products. Marketing, 47(1), 21-28. Doi:

https://doi.org/10.5937/markt1601021N

Palombo, V. J. (2009). Designing Marketing Channels for Global Expansion. Marketing Management Journal, 19(2), 64-71.

Pelton, L., Strutton, D., \& Lumpkin, J. (2016). Marketing Channels. Heriot-Watt University, Edinburgh Business School.

Radosavljević, K. (2017). Kanali marketinga poljoprivrednih proizvoda. Beograd: Institut ekonomskih nauka.

Revzan, D. A. (1961). Wholesaling in Marketing Organizations. New York: John Wiley \& Sons, Inc.

Rolnicki, K. (1998). Managing Channels of Distribution. New York: AMACOM.

Rosenbloom, B. (2013). Marketing Channels: A Management View. India: Cengage Learning Publications.

Szopa, P., \& Pękała, W. (2012). Distribution channels and their roles in the enterprise, Polish Journal of Management Studies, 6, 143-150.

Stanković, Đ. Lj. (2014). Trgovinska revolucija - Novi odnosi snaga u kanalima marketinga. Beograd: Čigoja štampa.

Stanković, J. (2018). Green marketing and green product. Economics of Sustainable Development, 2(2), 37-46.

Šmit, F.M. (2011, November). Sirevi. Progressive magazin, 90. available at http://progressivemagazin.rs/online/sirevi/, accessed 8.9.2019.

Tihi, B., Čičić, M., \& Brkić, N. (2006). Marketing. Sarajevo: Ekonomski fakultet. 
Vandecandelaere, E., Teyssier, C., Barjolle, D., Jeanneaux, P., Fournier, S., \& Beucherie O. (2018). Strengthening sustainable food systems through geographical indications. Rome: Food and Agriculture Organization of the United Nations.

Vasiljev, S. \& Sudarević, T. (2014). Marketing principi. Novi Sad: Prometej.

Veterinary Law, Official Gazette 93/2012, available at https://www.paragraf.rs/propisi/zakon_o_veterinarstvu.html

Zakić, N., Bozilović, S., \& Šijaković, I. (2018). Analysis and upgrading of value chain. Ekonomika, 64(4), 1-15. Doi: http://dx.doi.org/10.22004/ag.econ.290351

Zakon o trgovini, Službeni glasnik RS, broj 53/2015, available at https://www.paragraf.rs/propisi/zakon_o_trgovini.html

Zwart, T., \& McLeay F. (1997). Agricultural Marketing Channels: Determinants of Contract Choice, Discussion paper No.32, Department of Economics and Marketing, Lincoln University, Canterbury, 1-20. 